\title{
PRICE BEHAVIOUR IN INDIA'S COCONUT SECTOR
}

\author{
By
}

\author{
DR. PRAFULLA K. DAS ${ }^{1}$
}

\begin{abstract}
Coconut being a smallholder perennial crop, studies on the price behaviour of its products require serious consideration. A cursory look into the price structures of coconut, copra and coconut oil reveal that the price fluctuations are not only infrequent, but also most violent. The seasonal indices show different patterns for different products.

The Compound Growth Rates of wholesale prices for coconut products are found to be around 10 per cent per annum between 1970 and 1989. The indices however suggest that the relative prices in coconut sector are declining even though the absolute prices show significant growths. The correlation coefficients (r) between wholesale prices of coconut products are assessed as, 0.99 . The analysis of price behaviours in the important coconut product markets further reveals that those markets are highly competitive.

Attempts have been made to predict the prices of copra with the use of coconut oil prices; and the prices of coconut with the use of prices of either copra or coconut oil in the same market or in different markets. The prediction models are found out to be very good fit with the value of $r 2$ ranging between 0.98 and 0.99 .
\end{abstract}

\section{INTRODUCTION}

Coconut is a smallholder plantation crop in India. It has profound influence on the economic prosperity of millions of people engaged in its cultivation, processing and marketing. It is the only crop in the lauric oil group presently produced in this country in commercial scale and, therefore, enjoys a unique position among the oilseeds. In terms of oil equivalent the current production of coconut in India is about 690,000 tonnes. Further, it gives nearly four to eight times oil yield per unit area compared to other oilseeds commercialy grown in this country. However, in most parts of coconut growing areas in India it is grown under least care and management. And thus its full potential is not realised.

The reason for the neglect of this important crop is not far to seek. The first is the uncertainty in coconut prices. Contrary to popular belief the coconut farmers are not that handsomely paid. A cursory look into the price trends in coconut sector would reveal that the fluctuation in prices are frequent and violent. This instability could be attributed to more than one reason (Das, 1986).

This paper overviews the price behaviour in coconut sector since 1970-71. The scope of this study is, however, confined to Kerala the largest coconut production and marketing state in India.

\footnotetext{
${ }^{1}$ Head Division of Social Sciences, Central Plantation Crops Research Institute, Kerala, India.
} 


\section{MATERIALS AND METHODS}

The main part of this study covers the period 1970-71 to 1988-89. The data on wholesale prices for coconut, copra and coconut oil pertaining to three important markets in Kerala, namely, Calicut, Cochin and Alleppey were collected from the Coconut Development Board, Cochin. However, most of the analyses were limited to Calicut market. Our attempt to analyse the price behaviour at the farrngate as well as retail levels did not succeed because of the lack of readily available data over a sizeable period. The index numbers for the wholesale price were constructed considering 1970-71 as the base year. Following this, the relative price indices were computed by cleflating the wholesale price indices of coconut, copra and coconut oil with the corresponding wholesale price inclices for all commodities. Other analysis were done by using the statistical tools.

\section{RESULTS AND DISCUSSION}

Table 1 presents the average annual wholesale prices of coconut, copra and coconut oil in respect of Calicut market for the period 1970-71 to 1988-89. The widely fluctuating tendency of these prices from one period to the other is clearly evident in this table. The wholesale prices for 1000 nuts, for instance, sharply rose from Rs. 1260 in the year 1982-83 to Rs. 1905 in the following year, and further shot up to the record level of Rs.2605 in the next year. In other words, there was a price hike of 106.7 per cent in two years time. But the price of the same commodity suddenly declined by 53.4 per cent to Rs. 1215 in the year 1985-86 from the record level of the previous year and again moved sharply upwards to Rs. 1920 in the year 1986-87. The price trends for copra and coconut oil followed the similar pattern as that of coconut. Since, copra is produced by drying the coconut kemel and coconut oil is extracted from copra the market prices of those three commodities should therefore be expected to reflect a casual relationship. In this regard, the observed price behaviour is not merely a supply response of coconut and its products, but a supply response of oilseeds and oils as a whole.

TABLE 1. AVERAGE WHOLESALE PRICES OF COCONUTS, COPRA AND COCONUT OIL IN CALICUT MARKET DURING 1970-71 TO 1988-89.

\begin{tabular}{|c|c|c|c|}
\hline YEAR & $\begin{array}{c}\text { COCONUT } \\
\text { (RS/TONNES) }\end{array}$ & $\begin{array}{c}\text { COPRA } \\
\text { (RS/TONNES) }\end{array}$ & $\begin{array}{c}\text { COCONUT OIL } \\
\text { (RS/TONNES) }\end{array}$ \\
\hline $1970-71$ & 516 & 4,880 & 7,000 \\
$1971-72$ & 370 & 3,400 & 5,400 \\
$1972-73$ & 400 & 4,200 & 5,650 \\
$1973-74$ & 775 & 6,500 & 10,200 \\
$1974-75$ & 850 & 7,050 & 11,150 \\
$1975-76$ & 655 & 5,050 & 8,000 \\
$1976-77$ & 820 & 6,650 & 10,550 \\
$1977-78$ & 935 & 8,050 & 11,000 \\
$1978-79$ & 930 & 8,650 & 11,800 \\
$1979-80$ & 1,000 & 8,600 & 12,200 \\
$1980-81$ & 1,325 & 11,600 & 15,800 \\
$1981-82$ & 1,135 & 8,900 & 13,200 \\
$1982-83$ & 1,260 & 10,200 & 15,450 \\
$1983-84$ & 1,905 & 15,900 & 23,850 \\
$1984-85$ & 2,605 & 21,850 & 32,500 \\
$1985-86$ & 1,215 & 11,520 & 17,100 \\
$1986-87$ & 1,920 & 15,900 & 24,140 \\
$1987-88$ & 2,118 & 20,570 & 30,970 \\
$1988-89$ & 2,420 & 20,350 & 30,420 \\
\hline
\end{tabular}


Table 2 shows the average monthly wholesale prices of coconut in Calicut market during 1985-86 and 1986-87. This table suggests that the magnitude of price instability in this commodity even in the short-run is quite significant. In the month of May, 1985, for example, the price of 1000 nuts ruled at about Rs. 1283, while it was Rs. 1726 in the previous month. That means there was a 25.7 per cent price fall within a period of just 30 days. The standard deviations (SD) of the monthly prices of coconut were observed to be as high as 255.10 and 336.71 in the years 1985-86 and 1986-87, respectively. This sort of violent fluctuations in coconut prices speaks of the marketing problems particularly when the supply is regular and continuous year round, unlike the seasonal crops (Das, 1987). The seasonal indices for wholesale prices of coconut, copra and coconut oil, however, show slightly different patterns according to the influence of the demand response for those commodities (Table 3). It may be maintained here that the seasonal indices are lower during the period June to August as it is the off-season for copra making due to monsoon weather. On the other hand, during the period September to December the seasonal indices are seen to be higher because of the increasing consumer demand for coconut oil for meeting the needs of the festival season, which commence from Onam and ends at the Christmas. This period also coincides with the peak season for copra making as well as its crushing. Even though the summer months of January to May are favourable for copra making through sun drying of wet kemels of coconut, the acute power shortage in Kerala stands as a major constraint for the operation of oil mills during this period. Thus, the seasonal indices show a mixed trend in those months.

The Compound Growth Rates (CGR) of wholesale prices for coconut, copra and coconut oil in Calicut market are estimated to be around 10 per cent per annum between 1970 and 1989 (Table 4).

TABLE 2. FLUCTUATIONS OF WHOLESALE PRICES OF COCONUT IN CALICUT MARKET DURING 1985-87 (RS./1000 NUTS)

\begin{tabular}{|l|r|r|r|}
\hline \multicolumn{1}{|c|}{ MONTHS } & $1985-86$ & $1986-87$ & $\begin{array}{r}\text { PERCENTAGES } \\
\text { DEVIATION }\end{array}$ \\
\hline APRIL & 1,726 & 1,750 & 1.4 \\
MAY & 1,283 & 1,720 & 34.1 \\
JUNE & 1,126 & 1,450 & 28.8 \\
JULY & 1,042 & 1,380 & 32.4 \\
AUGUST & 1,025 & 1,669 & 62.8 \\
SEPTEMBER & 1,023 & 1,877 & 83.5 \\
OCTOBER & 1,005 & 2,086 & 107.6 \\
NOVEMBER & 900 & 2,000 & 122.2 \\
DECEMBER & 1,010 & 1,955 & 93.6 \\
JANUARY & 1,300 & 2,248 & 72.9 \\
FEBRUARY & 1,520 & 2,430 & 59.9 \\
MARCH & 1,560 & 2,478 & 58.8 \\
& & & \\
MEAN & 1,210 & 1,920 & \\
SD & 255.10 & 336.71 & \\
CV \% & 21.08 & 17.53 & \\
\hline
\end{tabular}


TABLE 3. SEASONAL INDEX FOR WHOSALE PRICES OF COCONUT, COPRA AND COCONUT OIL IN CALICUT MARKET DURING 1980-66

\begin{tabular}{|l|c|c|c|}
\hline \multicolumn{1}{|c|}{ MONTHS } & COCONUTS & COPRA & COCONUT OIL \\
\hline JANUARY & 108 & 105 & 99 \\
FEBRUARY & 114 & 102 & 94 \\
MARCH & 108 & 97 & 88 \\
APRIL & 105 & 91 & 92 \\
MAY & 98 & 91 & 93 \\
JUNE & 95 & 94 & 97 \\
JULY & 93 & 96 & 101 \\
AUGUST & 94 & 95 & 98 \\
SEPTEMBER & 102 & 99 & 104 \\
OCTOBER & 101 & 108 & 109 \\
NOVEMBER & 92 & 110 & 112 \\
DECEMBER & 111 & 110 & 111 \\
\hline
\end{tabular}

TABLE 4. COMPOUND GROWTH RATES OF COCONUT, COPRA AND COCONUT OIL IN CALICUT MARKET DURING 1970 TO 1989 (\% PER ANNUM)

\begin{tabular}{|l|c|}
\hline & CGR \\
\hline COCONUT & 9.97 \\
COPRA & 9.33 \\
COCONUT OIL & 9.34 \\
\hline
\end{tabular}

This study further explains that contrary to common man's belief, the real prices of coconut, copra and coocnut oil are tending to decline even though their current prices or absolute prices show a quite significant growth (Table 5). In other words, the prices of coconut sector in general are nor rising with the same proportion as that of the prices of other commodities, barring the severe deficit years such as 1973-74 and 1983-84. The year 1984-85 was, of course, a most unsual year of supply deficit for coconut products following an unprecedented drought not only in Kerala, but also in most parts of coconut growing areas.

Table 6 shows the correlation coefficients (r) between average whosale prices of coconut, copra and coconut oil during 1970 to 1989 . The ' $t$ ' values (0.99) are almost close to unity and thus confirm to the earlier observation that the degree of price relationship betweem coconut and copra, copra and coconut oil; and coconut and coconut oil is pretty close, further, Table 7 indicates the correlation coeffients (r) of whosale prices of coconut oil between Calicut and Cochin markets; Calicut and Alleppey market; Cochin and Bombay markets; and Alleppey and Bombay markets. This analysis also suggests that as far as coconut oil is concerned those markets behave in most close relationship and thus they are highly competitive as the ' $r$ ' values are almost unity. In other words, the degree of relationship between the major markets of coconut oil both inside and outside Kerala State is absolutely firm and stable. 
TABLE 5. WHOLESALE PRICE INDICES OF COCONUT, COPRA AND COCONUT OIIL IN CALICUT MARKET

\begin{tabular}{|c|r|r|r|r|r|r|}
\hline YEAR & \multicolumn{2}{|c|}{ ABSOLUTE PRICE INDICES } & \multicolumn{2}{|c|}{ RELATIVE PRICE INDICES } \\
\hline & COCONUT & COPRA & $\begin{array}{c}\text { COCONUT } \\
\text { OIL }\end{array}$ & COCONUT & COPRA & $\begin{array}{c}\text { COCONUT } \\
\text { OIL }\end{array}$ \\
\hline $1971-72$ & 72 & 70 & 77 & 68 & 66 & 73 \\
$1972-73$ & 78 & 86 & 81 & 67 & 74 & 70 \\
$1973-74$ & 150 & 133 & 146 & 107 & 95 & 105 \\
$1974-75$ & 165 & 144 & 159 & 94 & 82 & 91 \\
$1975-76$ & 127 & 103 & 114 & 73 & 60 & 66 \\
$1976-77$ & 159 & 136 & 151 & 90 & 77 & 85 \\
$1977-78$ & 181 & 165 & 157 & 97 & 89 & 84 \\
$1978-79$ & 194 & 177 & 169 & 104 & 95 & 91 \\
$1979-80$ & 180 & 176 & 174 & 83 & 81 & 80 \\
$1980-81$ & 257 & 238 & 226 & 100 & 93 & 88 \\
$1981-82$ & 220 & 182 & 189 & 78 & 65 & 67 \\
$1982-83$ & 244 & 209 & 221 & 84 & 72 & 76 \\
$1983-84$ & 369 & 326 & 341 & 117 & 103 & 108 \\
$1984-85$ & 505 & 448 & 464 & 150 & 133 & 138 \\
$1985-86$ & 235 & 236 & 244 & 66 & 66 & 68 \\
$1986-87$ & 372 & 326 & 345 & 97 & 85 & 90 \\
$1987-88$ & 410 & 422 & 442 & 102 & 104 & 110 \\
$1988-89$ & 441 & 394 & 410 & 101 & 90 & 94 \\
\hline
\end{tabular}

In this study, linear regression analysis was done to find out the trends lines for whosale prices of coconut, copra and coconut oil in Calicut market during 1970-71 to 1986-87. The regression equations are presented in Table 8. Since the coefficients of determination $\left(r^{2}\right)$ in all the three equations are 0.71 , this suggests that 71 per cent of the variotions in dependent variables are explained by the model whereas the remaining 29 per cent of the variations are contributed by the other factors including random fluctuation.

In an attempt to predict the price of each of coconut, copra and coconut oil with the knowledge of one of them, six regression equations were fitted (Table 9). The prediction models are found to be very good fit with the value of $r^{2}$ ranging between 0.98 and 0.99 . In other words, the price for one is the factor in determining the price of other because of their close dependency and relations.

TABLE 6. CORRELATION COEFFICENTS (r) BETWEEN AVERAGE ANNUAL WHOSALE PRICES OF COCONUT, COPRA AND COCONUT OIL DURING 1970 TO 19889

\begin{tabular}{|l|c|c|c|}
\hline & COCONUT & COPRA & COCONUT OIL \\
\hline COCONUT & 1.0000 & & \\
COPRA & 0.9938 & 1.0000 & \\
COCONUT OIL & 0.9952 & 0.9953 & 1.0000 \\
\hline
\end{tabular}


TABLE 7. CORRELATION COEFFICIENTS (r) OF WHOSALE PRICES OF COCONUT OIL IN MAJOR MARKETS DURING 1970-1989

\begin{tabular}{|l|c|c|c|c|}
\hline & CALICUT & COCHIN & ALLEPPEY & BOMBAY \\
\hline CALICUT & 1.0000 & 0.9970 & 0.9940 & 0.9970 \\
COCHIN & & 1.0000 & 0.9919 & 0.9932 \\
ALLEPPEY & & & 1.0000 & 0.9885 \\
BOMBAY & & & & 1.0000 \\
\hline
\end{tabular}

TABLE 8. WHOSALE PRICE TRENDS OF COCONUT, COPRA AND COCONUT OIL IN CALICUT MARKET DURING 1970-71 TO 1986-87

\begin{tabular}{|lllll|}
\hline COCONUT & $:$ & $308.55+$ & $98.31 \mathrm{~T}$ & $\left(\mathrm{r}^{2}-0.71\right)$ \\
COPRA & $:$ & $295.49+$ & $79.98 \mathrm{~T}$ & $\left(\mathrm{r}^{2}-0.71\right)$ \\
COCONUT OIL & $:$ & $416.47+$ & $120.80 \mathrm{~T}$ & $\left(\mathrm{r}^{2}-0.71\right)$ \\
\hline
\end{tabular}

TABLE 9. REGRESSION COEFFICIENTS FOR AVERAGE ANNUAL WHOLESALE PRICES OF COCONUT, COPRA AND COCONUT OIL IN CALICUT MARKET FOR THE PERIOD 1970 TO 1986.

\begin{tabular}{|c|c|c|c|c|c|}
\hline \multicolumn{2}{|c|}{ VARIABLES } & $\mathrm{a}$ & $b$ & $\mathrm{SE}(\mathrm{b})$ & $\mathrm{r}^{2}$ \\
\hline $\begin{array}{c}\text { DEPENDENT } \\
\text { (Y) }\end{array}$ & $\begin{array}{c}\text { INDEPENDENT } \\
\text { (N) }\end{array}$ & & & & \\
\hline (1) COPRA & COCONUT & 34.72 & 0.83 & 0.0239 & 0.988 \\
\hline (2) COCONUT & COPRA & $(-) 28.34$ & 1.19 & 0.0343 & 0.988 \\
\hline (3) COCONUT & COCONUT OIL & $(-) 26.66$ & 0.81 & 0.0204 & 0.990 \\
\hline (4) COCONUT OIL & COCONUT & 45.72 & 1.23 & 0.0312 & 0.990 \\
\hline (5) COCONUT OIL & COPRA & 2.82 & 1.47 & 0.0382 & 0.990 \\
\hline (6) COPRA & COCONUT OIL & 7.22 & 0.67 & 0.0174 & 0.996 \\
\hline
\end{tabular}

\section{REFERENCES}

Das, P.K. (1986). Movement of wholesale prices of Coconuts, copra and coconut oil in Kerala cluring the last two and half decades. J. Plant. Crops 14(2) : 105-114.

Das, P.K. (1987). Coconut marketing: Problems, Prospects and challenges. In: Proceedings of the National Seminar on Processing and Marketing of coconuts. Ed. by: P.K. Thampan et al. Coconut Development Board, Cochin. 134-141. 